\title{
Experimental study on mechanical properties of concrete by adding bottle caps and pet bottles in concrete
}

\author{
S. Divyabharathi ${ }^{*}$, S. Pavithran ${ }^{2}$ \\ ${ }^{1}$ PG Student, Department of Civil Engineering, K.S.Rangasamy College of Technology, Tiruchengode, Tamil Nadu, \\ India \\ ${ }^{2}$ Assistant Professor, Department of Civil Engineering, K.S.Rangasamy College of Technology, Tiruchengode,Tamil \\ Nadu, India \\ *Corresponding author E-Mail ID: divscivil25@gmail.com
}

Doi: https://doi.org/10.34256/irjmtcon70

\begin{abstract}
Concrete is widely used as construction material around the world and it's properties have been undergoing changes through technological advancement. Generally, concrete having four constituents materials namely cement, sand, coarse aggregate and water. Advancement in technology enhance human comforts and at the same time it causes damages to environment. Waste plastic bottles are major cause of solid waste disposal and also disposal of metal caps of soft drinks bottles are headache to environmental engineers and involve either to recycle or reuse. Here we are going to add metal caps and PET bottles in concrete to increase the strength. This project represents the results to study the behavior of concrete by adding of bottles caps and PET with dosage of $0.5 \%$ of weight of cement as fiber to reduce the cement content to achieve IS10262:2009 and IS456:2000 requirements. PET bottles and metal bottle caps are added to the concrete at $0 \%, 0.5 \%, 1.0 \%$ and $1.5 \%$ by volume of total mixture and also analysis of the compressive strength, split tensile strength, flexural strength and them mechanical properties are compared with the conventional concrete. Grade of concrete used in the project is M20. Mix ratio is $1: 1.5: 3$.
\end{abstract}

Keywords: Solid waste disposal, PET bottles, Recycle and disposal of metal caps.

\section{INTRODUCTION}

been used in construction industry throughout the world. It is an extremely versatile material and can be used for all types of concrete structures. Concrete is a composite construction material composed mainly for cement, water and aggregates. The rapid development of building and civil engineering after the Second World War is characterized by wide application of concrete as the basic material in all branches of the economy. Metal caps of soft drinks bottles and PET can be used as a partial replacement of cement.

\section{MATERIALS AND EXPERIMENTS}

\subsection{Cement}

Portland Pozzolana Cement also commonly known as PPC cement. These types of cement are manufactured by using pozzolanic materials as one of the main ingredient. The percentage of pozzolanic materials used in the preparation should be between 10 to 30 . If the percentage is 
exceeded, the strength of cement is reducing. Some of the pozzolanic materials used are volcanic ash, shales and certain type of clays. But in our country (In Indian) Fly ash is the main constitution used in preparation of cement.

\subsection{Fine Aggregate}

The aggregate which pass through $4.75 \mathrm{~mm}$ IS sieve and entirely retain on 75 microns IS sieve is called fine aggregate. It may be natural sand, crushed stone sand or crushed gravel sand. The minimum particle size of fine aggregate is $0.075 \mathrm{~mm}$ and the maximum particle size is $4.75 \mathrm{~mm}$. the materials having particle size varying from 0.002 to $0.06 \mathrm{~mm}$ is termed as slit and smaller particles are called clay.

\subsection{Course Aggregate}

The aggregate which pass through $75 \mathrm{~mm}$ IS sieves and entirely retain on $4.75 \mathrm{~mm}$ IS sieve is known as coarse aggregate. It may be crushed gravel or stone, uncrushed gravel or stone or partially crushed gravel stone. The minimum particle size of coarse aggregate is $4.75 \mathrm{~mm}$ and the maximum particle size is $75 \mathrm{~mm}$. If the size is more than $75 \mathrm{~mm}$, then the aggregate is called cyclopean aggregate.

Table 2.1 properties of fine and coarse aggregate

\begin{tabular}{|l|l|l|l|}
\hline S.NO & Property & Coarse aggregate & Fine aggregate \\
\hline 1 & Specific gravity & 2.85 & 2.65 \\
\hline 2 & Water Absorption & $0.55 \%$ & $0.65 \%$ \\
\hline 3 & Dry loose bulk Density & $1322 \mathrm{~kg} / \mathrm{cum}$ & $1468 \mathrm{~kg} / \mathrm{cum}$ \\
\hline 4 & Fineness modulus & 4.16 & \\
\hline 5 & zones & & 2.64 \\
\hline 6 & Silt(volume) & - & II \\
\hline 7 & Abrasion value\% & 22 & $2 \%$ \\
\hline 8 & Impact value\% & 16 & - \\
\hline 9 & Crushing value\% & 23 & - \\
\hline
\end{tabular}

\subsection{Water}

It is the most important and least expensive ingredient of concrete. A part of the mixing is utilized in the hydration of cement to form the binding matrix in which the inert aggregate are held in suspension until the matrix has hardened. The remaining water server as a lubricant between the fine and coarse aggregate and makes the concrete workable.

\subsection{Pet Bottles}

The polyethylene (PET) bottle which can easily be obtained from the environment with almost no cost is shredded and added into ordinary concrete to examine the behaviour of various specimens. the chemical and physical properties of PET bottles are in the table 2.2 
Table 2.2 properties of PET bottles

\begin{tabular}{|c|c|c|}
\hline property & unit & value \\
\hline Density & $\mathrm{g} / \mathrm{cm}^{3}$ & $0.91-0.94$ \\
\hline Tensile strength & Psi (pound/sq.in) & $3200-5000$ \\
\hline Water absorption (24hrs) & $\%$ & 0.01 \\
\hline Elongation & $\%$ & $3-700$ \\
\hline Softening point, $\mathrm{T}_{\mathrm{g}}$ & ${ }^{0} \mathrm{C}$ & $140-150$ \\
\hline Melting point, $\mathrm{T}_{\mathrm{m}}$ & ${ }^{0} \mathrm{C}$ & $160-166$ \\
\hline Thermal expansion & $10-5 \mathrm{in} . / \mathrm{in} .{ }^{0} \mathrm{C}$ & $5.8-10$ \\
\hline Specific volume & $\mathrm{Cm}^{3} / \mathrm{lb}$ & $30.4-30.8$ \\
\hline Crystallinity & & $>=45$ \\
\hline Acetaldehyde & $\mathrm{Ppm}$ & $<=3$ \\
\hline Carboxyl end group & $\mathrm{Mol} / \mathrm{t}$ & $<=20$ \\
\hline
\end{tabular}

\subsection{Mix Proportions}

Table 2.3 Mix proportions

\begin{tabular}{|c|c|}
\hline Materials & Mass \\
\hline Cement & $465 \mathrm{~kg} / \mathrm{m}^{3}$ \\
\hline Fine aggregate & $657.92 \mathrm{~kg} / \mathrm{m}^{3}$ \\
\hline Coarse aggregate & $1169.65 \mathrm{~kg} / \mathrm{m}^{3}$ \\
\hline Water & 186 liters \\
\hline
\end{tabular}

\subsection{Compressive Strength}

The compressive test is performed on standard cubes of conventional concrete and replacement concrete(micro silica and fly ash) at various percentage such as 10\%,20\%, and $30 \%$ after 7 days of immersion in water for curing. The size of the cube is $150 \times 150 \times 150 \mathrm{~mm}$. The compressive strength results are tabulated as follows.

\begin{tabular}{|c|c|}
\hline Samples & Average comp.strength(N/mm $\mathbf{~})$ \\
\hline 1 & 15.33 \\
\hline 2 & 20.90 \\
\hline 3 & 16.56 \\
\hline 4 & 28.81 \\
\hline 5 & 32.75 \\
\hline 6 & 31.27 \\
\hline
\end{tabular}




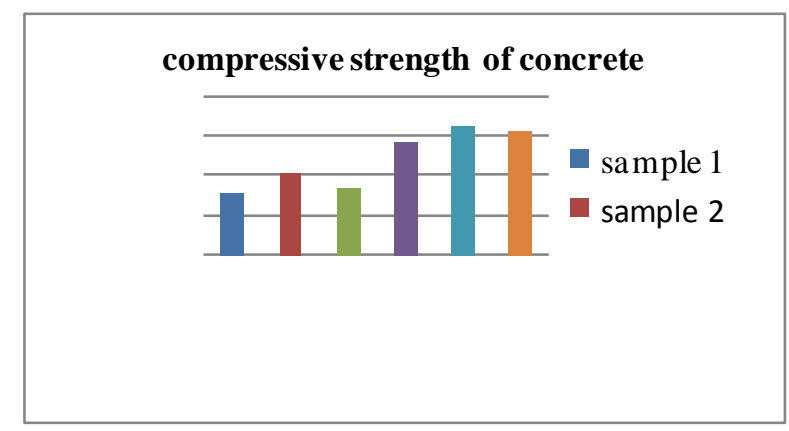

Fig 1-Compressive strength of concrete

\subsection{Split Tensile Strength}

The average results of tensile strength of the concrete cylinders at the end of the 28 days casted using pet bottles are calculated. The length of the specimens shall not be less than the diameter testing and comparison of results, unless otherwise specified the specimens shall be cylinder $150 \mathrm{~mm}$ in diameter and $300 \mathrm{~mm}$ long.

Table 2.4-Split tensile strength of concrete

\begin{tabular}{|c|c|}
\hline Samples & Average Tensile Strength(N/mm $\mathbf{~})$ \\
\hline 1 & 2.05 \\
\hline 2 & 2.25 \\
\hline 3 & 1.98 \\
\hline 4 & 2.28 \\
\hline 5 & 3.47 \\
\hline 6 & 3.00 \\
\hline
\end{tabular}

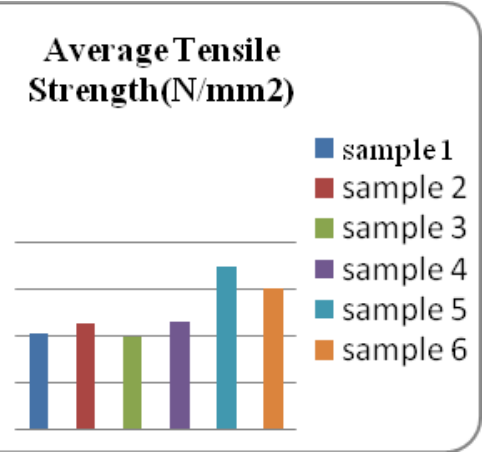

Fig 2. Tensile strength of concrete

\subsection{Flexural Strength}

Table 2.5 Flexural strength of concrete

\begin{tabular}{|c|c|}
\hline Samples & Average Flexural Strength(N/mm $\left.{ }^{\mathbf{2}}\right)$ \\
\hline 1 & 2.44 \\
\hline 2 & 3.84 \\
\hline 3 & 3.54 \\
\hline
\end{tabular}




\begin{tabular}{|c|c|}
\hline 4 & 4.65 \\
\hline 5 & 7.54 \\
\hline 6 & 6.7 \\
\hline
\end{tabular}

The average results of flexural strength of the concrete prism at the end of the 28 days casted using plastic pellets are calculated. Flexural strength is a measure of an unreinforced concrete prism. Short period of drying can produce an short drop in flexural strength. The flexural strength is expressed in the form of modulus of rupture. Specifications and investigation of apparent low strengths should take into account the higher variability of flexural strength result.

Average Flexural Strength(N/mm2)

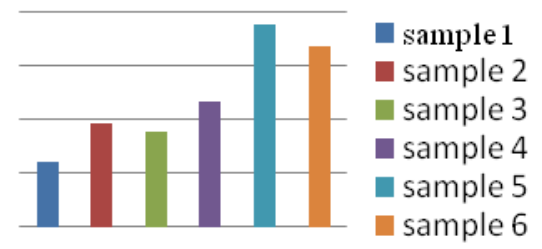

Fig 3. Flexural strength of concrete

\section{CONCLUSIONS}

Compressive strength of the concrete can be stepped up with the prominent from the different waste material which is hazardous from the view of solid waste disposal. These materials can be plastic bottles and metal caps which give fiber properties to the concrete and reliable fiber reinforce concrete can be made. The cube compressive strength, split tensile strength and flexural strength increases for the optimum of $1 \%(0.5 \%$ of PET bottles $+0.5 \%$ of bottle caps). The compressive strength values of conventional concrete and optimum percentage are $28.81 \mathrm{~N} / \mathrm{mm}$ and $32.75 \mathrm{~N} / \mathrm{mm}$ respectively.

\section{REFERENCES}

1. G.C.Behera,R.K.Behera "Increases in strength of concrete by using Bottle caps" IRJET, Volume:02, Issue:03 June 2015.

2. Darshan N, Rajani V Akki, sharath B P "Experimental study on Hardened properties of concrete by Using Soft Drink Bottle Caps as Partial Replacement for Coarse Aggregate"IJETST, Volume:01,Issue:08, October 2014.

3. Manaswini C, Vasu Deva "Fiber Reinforced Concrete from Industrial Waste_ A Review" IJIRS, Volume:02,Issue:12,December 2015.

4. SampadaChavan, PoojaRao "Utilization of Waste PET bottle fiber in concrete as an innovative in Building Materials” IRJET, Volume:05,Issue:01 Jan 2016.

5. shonakPurohit, PriyankaVasava, Shefali Christian, Krishna Patel, MayurikaVasava, "Evaluating strength of concrete using Bottle Caps and PET" IJAERD, Volume 04,Issue:03,March 2017.

6. M.S.Setty, "Concrete Technology" S.Chand and company Ltd, Third Edition, pp608, 1982.

7. IS 383-1970: "Specification for coarse and Fine Aggregates from Natural Sources for Concrete"(second Revision),Bureau of Indian Standard, ManakBhavan,BahadurshahZafarMarg,New Delhi,1970. 
S. Divyabharathi \& S. Pavithran / International Research Journal of Multidisciplinary Technovation /2019, 1(6), 490-495

8. IS 383-1970: "Specification for Coarse and Fine Aggregates from Natural Sources for Concrete" (second Revision),Bureau of Indian Standard, ManakBhavan, BahadurshahZafarMarg, New Delhi,1970. 